\title{
Volume 24 Number 1
}

\section{9}

\section{Children}

\section{Australia}

\section{In this issue ...}

\section{Creating social capital}

The distinctive role of the non-government agency

Partnerships between parents and teachers in child protection

Social injustice for 'at risk' adolescents and their families

Negotiating change

Refounding and MacKillop Family Services

'It must be because ...'

Non-biological care and mental health

Part II The pattern of referrals to Alfred CAMHS

On the subject of children

Children are the best people to tell us what is wrong with child welfare 


\section{Children Australia}

Volume 241999

EDITOR: $\quad$ Lloyd Owen

Senior Lecturer

Dept of Social Work \& Social Policy

La Trobe University

BOOK REVIEW EDITOR: Dr June Allan

Senior Lecturer

School of Social Science \& Planning, RMIT
Children Australia is a quarterly journal which aims to provide an opportunity for senvice providers, academics and others concerned with children and families to report on their work, to raise issues and to share their views.

The opinions expressed in Children Australia are those of its contributors and are therefore not necessarily those of the Editor or members of the editorial board.

\section{NATIONAL EDITORIAL BOARD}

$\mathrm{ACT}$

New South Wales

Northern Territory

Queensland

South Australia

Tasmania

Victoria

Western Australia

Adviser

Asia-Pacific Region
Dr Howard Bath Executive Director, Marymead Child \& Family Centre

Dr Elizabeth Fernandez

Senior Lecturer, School of Social Work

University of New South Wales

Dr Sharon McCallum

Senior Lecturer, Social Work, Faculty of Law, Arts \& Business Northern Territory University

Ms Chris-Maree Sultmann

Program Development Co-ordinator, Families Program

Department of Families, Youth \& Community Care

Dr Freda Briggs

Professor of Child Development

School of Psychology

University of South Australia

Ms Scilla Weber

Consultant for Policy and Project Management

Child, Youth and Family Support

Department of Health and Human Services

Ms Margarita Frederico

Senior Lecturer, Department of Social Work \& Social Policy

La Trobe University

Dr Chris Goddard

Director, Child Abuse and Family Violence Unit

Monash University

Dr Tom Keating

Pro Vice Chancellor, Wodonga Campus

La Trobe University

Dr Frank Ainsworth

Senior Lecturer, Dept of Community Services \& Social Sciences

Joondalup Campus

Edith Cowan University

Dr Jinchao Yao 


\section{CONTENTS}

Editorial........................................................................................ 2

Creating social capital ........................................................................... 4

The distinctive role of the non-government agency

Dorothy Scott

Partnerships between parents and teachers in child protection.

Russell M.F. Hawkins and Freda Briggs

Social injustice for 'at risk' adolescents and their families. 14 Frank Ainsworth

Negotiating change 19

Refounding and MacKillop Family Services

John Honner

'It must be because ...' Non-biological care and mental health.

Part II The pattern of referrals to Alfred Child and Adolescent Mental Health Service Cas O'Neill

News from AAYPIC

Book reviews.

M Significant harm: Unravelling child protection decisions and substitute care careers of children

D. Behaviour management in context: '... A very good place to start'

Not the last word: point and counterpoint 33

On the subject of children

Children are the best people to tell us what is wrong with child welfare

Chris Goddard

\section{SUBSCRIPTIONS}

$\begin{array}{ll}\text { Standard } & \$ 55 \mathrm{pa} \\ \text { Concession } & \$ 40 \mathrm{pa} \\ \text { Overseas } & \$ 75 \mathrm{pa}\end{array}$

For further information, or to advise change of address, please contact: Larraine Redshaw Tel: (03) 97921301 Fax: (03) 97921550

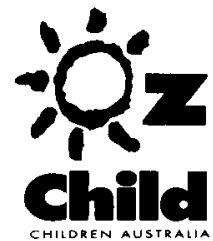

The financial support of Oz Child: Children Australia is gratefully acknowledged
The financial support of the

La Trobe University Publications Committee is gratefully acknowledged 